\title{
It's Not Only Green That Matters: Understanding Education for Sustainability in Schools
}

\author{
Sonja Kuzich, Curtin University of Technology, Australia
}

\begin{abstract}
Sustainability is the buzzword of the decade with so much being touted under this banner that it has become both at once, potent in meaning and, at the same time, meaningless. There are many school leaders and whole school communities that have signed ip to be a 'sustainable school'. With schools ready to embrace the 'visible' aspects of sustainability such as the 'kitchen garden' and 'environmental activities', many fundamental aspects of sustainability are being obscured by 'green'. This paper challenge us to think deeply about what this enterprise called sustainability is, how teachers have become a central notion in a political and policy agenda, and to consider education in terms of all four pillars of sustainability.
\end{abstract}

Keywords: Education For Sustainability, Teachers, Schools, Policy, Environment, Green

If you are thinking a year ahead, sow seed.

If you are thinking ten years ahead, plant a tree.

If you are thinking one hundred years ahead, educate the people.

Kuan Tzu, Chinese Poet (500 B.C.)

$\mathrm{T}$

HERE IS A sense of growing urgency to respond to concerns about the future of the planet. Sustainability has emerged as a new paradigm that holds the seeds of promise for a collective response to our current global issues. Whilst many of us can quickly identify what could possibly be making our future unsustainable, there is little agreement about what sustainability actually is. The trajectory of growth of the sustainability phenomenon can be traced back to the 1970's (Woolterton, 2003; Tilbury, 2005). However, it wasn't until the 1980's that the specific concept of 'sustainability' came into being through the World Conservation Strategy and the Brundtland Report, Our Common Future (WCED, 1987; Tilbury \& Cooke, 2005). This provided what has become the most widely quoted definition of sustainable development, 'meeting the needs of the present without compromising the ability of future generations to meet their own needs' (WCED, 1987, p.43). Since then sustainability has become a 'buzzword' which is ill defined but sprayed around with regularity like other aerosol words such as excellence, quality and choice (Woolterton, 2003, p. 56).

Although the Brundtland Report noted the usefulness of education in building capacity to deal with issues such as population and human resources, food security, species and ecoystems, energy and industry production it was not until Agenda 21, a pivotal document signed at the Rio de Janeiro Summit on environment and development in 1992, that an international commitment to 'education for sustainable development' crystallized (Woolterton, 2003; Martin, Summers \& Sjerps-Jones, 2007). This document articulated the connection

The International Journal of Environmental, Cultural, Economic and Social Sustainability

Volume 7, Number 3, 2011, http://www.Sustainability-Journal.com, ISSN 1832-2077

○ Common Ground, Sonja Kuzich, All Rights Reserved, Permissions:

cg-support@commongroundpublishing.com 
between education and sustainability for the first time, positioning education as critical to the kind of systemic change required (Sterling, 2003). Central to this was the notion of education precipitating 'a profound change in mindset' (Goldie, Douglas \& Furnass, 2005, p. 3) to prevent future catastrophe.

At the third international gathering, the United Nations' World Summit on Sustainable Development held in Johannesburg in 2002, it became clear that there had been little change over the previous decade. An outcome of the Summit was a formalisation of the recognition that education needs to play a stronger role in meeting the challenge of sustainability. This was actioned through a declaration of the UN Decade of Education for Sustainable Development with UNESCO leading it, from 2005 to 2014. This reflected a change in the dominant approach of educating 'about' the environment to a need for educating 'for' sustainability (Henderson \& Tilbury, 2004). Like Fien (2001) and Pezzoli (1996) UNESCO conceptualised the pillars of sustainability as being four interdependent systems: environmental, political, economic and social/cultural.

In leading this decade of change UNESCO identified its primary aim as 're-orienting the current formal education system' (UNESCO, 2005, p. 57). In order to do so, education for sustainable development was to promote (UNESCO, 2006, p 16):

- respect for dignity and human rights of all people throughout the world and a commitment to social and economic justice for all;

- respect for the human rights of future generations and a commitment to intergenerational responsibility;

- respect and care for the greater community of life in all its diversity which involves the protection of the Earth's ecoystems; and

- respect for cultural diversity and a commitment to build locally and globally a culture of tolerance, non-violence and peace.

Teachers were identified as central to the precipitation of change through their influence on students. The powerful multiplier effect of over 60 million teachers in the world and every one a potential change agent in bringing about a change in knowledge, values, attitudes and behaviours needed for a sustainable society it was reasoned would make this change possible (Woolterton, 2003; Chambers, 2009.). The paradox of this appeal to education is that the most highly educated nations leave the deepest ecological footprints and have contributed most to unsustainable practices (UNESCO, 2002). Sterling (2003, p. 46) asserts:

Most mainstream education sustains unsustainability - through uncritically reproducing norms, by fragmenting understanding, by sieving winners and losers, by recognizing only a narrow part of the spectrum of human ability and need, by an inability to explore alternatives, by rewarding dependency and conformity, and by servicing the consumerist machine.

The question seems to be if education is deemed essential in moving towards sustainability what kind should it be? According to UNESCO (2005, p. 17; Nolet, 2009, p. 417) traditional educational approaches need to be re-oriented towards: 
- interdisciplinary and holistic learning: learning for sustainability embedded in the whole curriculum, not as a separate subject;

- values-driven: it is critical that the assumed norms - the shared values and principles underpinning sustainable development - are made explicit so that can be examined, debated, tested and applied;

- critical thinking and problem solving: leading to confidence in addressing the dilemmas and challenges of sustainable development;

- multi-method approaches such as word, art, drama and debate, experience different pedagogies that model the processes. Teaching that is geared simply to passing on knowledge should be recast into an approach in which teachers and learners work together to acquire knowledge and play a role in shaping the environment of their educational institutions;

- participatory decision making: learners participate in decisions on how they are to learn;

- locally relevant information: addressing local as well as global issues, and using the language(s) which learners most commonly use.

\section{Education for Sustainability and the Environment}

Sustainability emphasizes the interconnectedness of environmental, economic, social and political systems and requires transformation of values and beliefs (Nolet, 2009; Gallopin, 2003). Wals and Jickling (2002, p. 227) see that for schools to meet the challenge of sustainability it will require 'deep debate about normative, ethical and spiritual convictions'. Sterling (2003, p. 48) advocates a shift from what many of the educational policies and international documents promote, that is education as 'an agent of change', to education as 'subject' of change. This is a 'macroshift' (Lazslo, 2001) that is not easily appreciated in schools.

In Australia the imprimatur for schools to adopt education for sustainability came with the document Educating for a Sustainable Future- A National Environmental Education Statement for Australian Schools (DEH, 2006) and Living Sustainably: The Australian Government's Action Plan for Education for Sustainability (NAPESD) (DEWHA, 2009). Environmental and sustainability issues have begun to permeate into Australian schools over the last fifteen or so years. The first example of a government supported systemic initiative to achieve this been the Australia wide Australian Sustainable Schools Initiative (AuSSI) that commenced in 2002 in NSW and Victoria. The vision for AuSSI is to support schools and their communities to become sustainable. Currently this program has been implemented into over two thousand schools (over a quarter of all Australian schools) (Australian Government, 2008). Alongside such a systemic approach many schools have developed their own approaches to 'sustainability'.

The distinction between environmental concerns and a broader, more holistic notion of sustainability has often become blurred. There is a tendency to conflate education for sustainability (EfS) and education for sustainable development (ESD) with Environmental Education (EE). This has resulted from the gradual abandonment of the original holistic roots of ESD that recognised peace and social justice (Selby \& Kagawa, 2010).

Ferreira, Ryan and Tilbury $(2006$, p. 16) identify the difference between environmental education and education for sustainability (EfS) being that the latter 'seeks to address the 
systemic causes of environmental problems through holistic and integrated means. This means that issues are understood in their totality: not just as environmental issues but also as economic, social and political issues'. Nolet (2009) reminds us that sustainability represents a constellation of 'large ideas' only one of which is environmental impact. Previous approaches to introducing education for sustainability into the school curriculum and context have included as Duggan, Smith and Thomsen (2009, p. 2) describe 'developing environmental education-based learning experiences that can be 'tacked-on' to existing curriculum in order to provide a 'green glow' to the program'. Sterling (2003, p. 67) puts it plainly: 'Sustainability is not just about 'the environment' but about the future of individuals and whole societies. It is not a separate agenda, but the agenda which affects all; one which we are foolhardy to ignore and wise to engage with. It is a question of survival, security, and well-being'.

Although current discourse views education for sustainability in a more holistic way Duggan, Smith and Thomsen (2009) contend that this has made very little impact in the school context and differs very little from the previous environmental education focus, largely ignoring the interconnectedness of cultural political, social and economic aspects. Selby and Kagawa (2010; see also Selby, 2006) note that whilst the initial conceptualisation of sustainability embraced social issues it has largely been economic and environmental issues that have gained prominence in education for sustainable development. There appears to be a disjunction between policy imperatives for sustainability and implementation at the school level.

\section{The Translation of Sustainability to Schools}

Flowers and Chodkiewicz (2009) categorise the nature of change that result from school based sustainability initiatives as ranging from conservation, to reformist or transformative views of change on the other. They explain that conservative views on change, as the name implies, in fact seek preservation of the status quo and to minimize change. Change is considered reformist when improvements or alterations are made often aligned with a specific goal such as cleaning up a waterway, reducing litter and waste and cutting power or water consumption (Flowers \& Chodkiewicz, 2009). The effect of such efforts, Flowers and Chodkiewicz (2000) argue, is that only the obvious symptoms are treated and there is little consideration of underlying causes and the necessity for deeper change to address the issues long term. It is, they note, the most commonly observed type of change even amongst schools that are heavily engaged in formal sustainability initiatives, such as the AuSSI program. A superficial adoption of education for sustainability where it becomes just another curriculum box to be ticked characterise much of 'education for sustainability'. Littledyke, Taylor and Eames (2009, p. 5) note that despite some very positive initiatives (such as the AuSSi Schools program) a key problem in the implementation of education for sustainability in primary schools is that although teachers clearly had a concern for the environment there was a 'poor conceptual understanding of environmental and sustainability issues, and the social, cultural, economic and political dimensions of these issues'. This is confirmed by the research of Pepper and Wildy (2008, p. 626) who found that much of the behaviour and resources that schools identified as addressing education for sustainability were in effect only narrowly focused on environmental education They concluded that schools did not 'distinguish between environmental education, with its narrow focus on the environment, and education for sus- 
tainability, with its broad focus on the integration of environment, economics and social justice'.

Teachers and schools pressed for time and induced by offers of exciting new programs, professional development opportunities for staff (often coupled with injections of funds) to support sustainability initiatives may become preoccupied too quickly with an instrumental and pragmatic approach of embedding education for sustainability into their schools. Jickling and Wals $(2008$, p. 6) note that the approach is on of 'roll up your sleeves and start implementing!' Selby and Kagawa (2010) voice concerns that educators may not see the 'forest for the trees', being preoccupied with the minutiae of kitchen gardens and recycling programs but not really have the opportunity, nor the realization, that deeper questions need to be grappled with. This is not a surprising development as evidenced by research conducted by Raudsepp and Heidmets (2005) who found that even professionals, whose core focus of their working life was engagement in sustainability, acknowledged that sustainable development involved more than just environmental factors but nevertheless tended to focus less on the social and economic aspects.

Given that teachers currently in our education systems have not been, on the whole, exposed to issues of sustainability throughout their own education and teaching career it is not unexpected that only the 'visible' aspects of sustainability are targeted. Teaching towards sustainability is more complex than teachers upgrading their own knowledge about the environment and environmental science or embedding environmental content into the existing curricula (Fien \&Maclean, 2000). Education for sustainability demands 'new sets of skills such as envisioning, critical thinking and reflection, dialogue and negotiation, collaboration and building of partnerships' (Tilbury \& Wortman, 2004, p. 12). Ferreira, Ryan and Tilbury (2006, p. 17) claim that successful examples of whole-school education for sustainability are very rare and suggest some reasons for this may be:

- teachers do not have the skills to address the complex and varied intricacies of dealing with sustainability at all levels of school management (i.e from classroom to school governance)

- teachers are inadequately prepared for challenges of participatory pedagogy, interdisciplinarity, action learning, and critical thinking.

- investment of knowledge and drive in a 'school sustainability champion' leads to a collapse of sustainable schools initiatives when that staff member leaves.

To complicate matters the use of the related term 'sustainable' has reached the public consciousness through its widespread use within the popular media, in government policy documents and as a means of marketing a variety of enterprises. This has become associated with Orr's (1992) technological sustainability and refers exclusively to environmental impacts (Nolet, 2009). A fundamental error propagated by a solely technocentric environmental approach to sustainability is that students are led to believe that it is simply a matter of 'finding scientific or technological solutions to environmental problems without addressing their root social, political and economic causes (Department of Environment, Sport \& Territories, 1997; Fien, 1993)

Whilst 'sustainability' and 'sustainable' are not incompatible the latter is a narrower definition that has made it into common parlance and has obliterated the broader perspective required of 'sustainability' (Nolet, 2009). It is therefore not unexpected that when schools 
develop sustainability initiatives their focus revolves around the 'green' environmental aspects only as these are most commonly associated with the notion of being or becoming 'sustainable'.

\section{Systems and Silos.}

Environmental education with a focus on knowledge 'about' the environment is necessary of course, however it is not sufficient (Sterling, 2003). This is clearly evidenced in the outcomes of decades of environmental education that has not been able to have any significant effects on behaviour (Nolet, 2009). Cartright (2010) reaffirms 'sustainable human living cannot be achieved by "just doing things that help the environment" - by "being green"" and laments that many of our policies and educational initiatives appear to be based on this environmental model. Taylor, Nathan and Coll (2003) agree that the assumption that knowledge translates into appropriate action is simplistic and deterministic. What sustainability has brought to our attention is that "environmental and development problems cannot be understood without reference to social, economic and political values, and that managing the global crisis will depend upon changes in personal values, lifestyle choices, and global patterns of development and trade' (Department of Environment, Sport and Territories, 1997, n.p). Environmental knowledge alone is inadequate to challenge our 'mental models' (Tilbury $\&$ Cooke, 2005) or 'frames of mind' (Bonnett, 2002) that have led to unsustainable development. Martin, et. al (2007), Sterling (2003) and Orr (2004) posit that the multidimensional nature of sustainability and the need to address the root causes of unsustainability takes the focus a quantum leap beyond only environmental issues.

The corralling of expertise and stewardship of education for sustainability initiatives in schools can tend to be the province of the teacher with the interest or background in science, geography or the environment (Davis \& Ferreira, 2009). Lewis, Baudains and Mansfield's (2009) longitudinal study of a sustainable school initiative revealed that these 'sustainability champions' may be the only ones on staff who have some understanding of the complex systems thinking that is required. Traditional education has been neatly compartmentalised into the learning area/subject 'silos' that can inhibit the interdisciplinary connections required to deal with sustainability issues. Orr $(2004$, p. 56) illustrates the problem:

... students graduate without knowing how to think in whole systems, how to find connections, how to ask big questions, and how to separate the trivial from the important. Now more than ever, however, we need people who think broadly and who understand systems, connections, patter $n s$, and root causes.

Woolterton (2003, p. 103) notes the apparent conflict and contradiction even with EfS policy documents such as the Australian Sustainable Schools statement: 'Sustainable schools promises to make environmental education and improved environmental practice, without imposing upon traditional education subject areas '. This apolitical and uncritical approach with traditional disciplinary separation, claims Woolterton (2003), will not yield the change that is supposedly desired.

What is clear for many advocates of education for sustainability is that it cannot be addressed by the same kind of education that created it (Orr, 1992; Sterling, 2003; Davis, 2010). Education for sustainability is more than just an acquisition of knowledge and skills, in its 
fullest sense it is action oriented (Department of Environment, Water, Heritage and the Arts, 2010, p. 4):

Education for sustainability can be empowering, and an antidote to a sense of helplessness. It equips students to act, individually and collectively, in ways that cont ribute to sustainability. It provides the opportunity for students to explore and evaluate contested and emerging issues, gather evidence and create solutions... it can enable students to become effective citizens and active change agents by helping them deal with complexity and uncertainty. It can also help them to understand that there is rarely a single solution..

Sterling (2009) wonders at the paradox of expecting educational institutions, still largely governed according to the policies and practices of a previous age, to take on the responsibility of leading the world to a new, stable, secure and livable future. Education for sustainability is ultimately premised on a radical shift in our current dominant mechanical to an emerging ecological worldview. The contrasts in the views are illustrated below (Sterling, 2003, p.271):

- Understanding of the natural and social world by taking it to pieces and examining the pieces versus understanding the world as a living system and our place in it.

- Valuing compartments, silos, fragments, linear thinking, clear cause and effect, transmission (passing on facts etc) versus valuing interconnectedness, systems, integrated thinking, collaboration, participation, creativity, transformation.

- Environment, society (culture), economy and politics are considered separate versus environment, society (and culture), economy and politics acting as nesting systems within and connected to each other.

To achieve this magnitude of educational reorientation means a complete overhaul or transformation of the paradigm, purpose, policy and practice of education systems (Sterling, 2009).

\section{Conclusion}

The role of schools in moving towards a more sustainable, society has largely been almost exclusively focused on environmental aspects. Many schools and their communities have embraced 'sustainability' and evidenced their commitment through the establishment of kitchen gardens, recycling programs, water conservation measures and the like. This paper has argued that these measures are largely 'cosmetic' and have not addressed the fundamental way we see and engage with the world. Whilst knowing about the environment is an essential component, it in no way suffices as, nor supplants, 'education for sustainability'. Despite this, it represents a tangible first step toward sustainability and schools and educators are able to build upon this work already occurring in their schools through adopting a more critically reflective approach. If education for sustainability is to be realized an important next step for schools is to re-conceptualise their practice, values and attitudes, and re-orient themselves to the interconnected vision of all four pillars of sustainability: society, economy, politics and environment. 


\section{References}

Australian Government (2008). Australian Sustainable Schools Initiative (AuSSI). Retrieved from $\mathrm{http}: / / w w w . e n v i r o n m e n t . g o v . a u / e d u c a t i o n / a u s s i / i n d e x . h t m l$

Bonnett, M. (2002). Education for sustainability as a frame of mind. Environmental Education Research, $8(1), 9-20$.

Cartwright, W. (2010). Educational Priorities for Strong Sustainability in New Zealand. New Zealand Association for Environmental Education (NZAEE) Conference, Hastings, 19 January 2010. Retrieved from http://www.phase2.org/

Chambers, D. (2009). Making the most of the multiplier effect: Teacher education as a key to sustainability. Presentation at the 9th International Conference of Australasian Campuses Towards Sustainability. September 30th - October 2nd 2009:Macquarie University, North Ryde, NSW, Australia

Davis, J. (Ed.) (2010). Young children and the environment: Early education for sustainability. Melbourne, Australia: Cambridge University Press.

Davis, J.M., \& Ferreira, J. (2009). Creating cultural change in education: a proposal for a continuum for evaluating the effectiveness of sustainable schools implementation strategies in Australia. Australian Journal of Environmental Education, 25, 59 - 70.

DEH. (2006), Education for a sustainable future: A national environmental education statement for Australian schools. Australian Government: Canberra.

Department of Environment, Sport and Territories (1997). Teaching for a sustainable world:International edition. Retrieved from http://www.environment.gov.au/education/publications/tsw/index.html

Department of the Environment, Water, Heritage and the Arts [DEWHA] (2009). Living sustainably: The Australian government's national action plan for education for sustainability. Australian Government Department of Environment, Water, Heritage and the Arts. Canberra, ACT, Retrieved from http://www.environment.gov.au/education/nap/

Department of the Environment, Water, Heritage and the Arts [DEWHA] (2010). Sustainability curriculum framework: a guide for curriculum developers and policy makers. Australian Government Department of Environment, Water, Heritage and the Arts. Canberra, ACT. Retrieved from http://www.environment.gov.au/education/publications/curriculum-framework.html

Duggan, M.S., Smith, T.F., \& Thomsen, D.C. (2009). A monitoring and evaluation framework for transformative change from sustainability programs in secondary schools. AARE Conference, Melbourne.

Ferreira, J., Ryan, L. ,\& Tilbury, D. (2006). Whole-school approaches to sustainability: A review of models for professional development in pre-service teacher education. Canberra: Australian Government Department of the Environment and Heritage and the Australian Research Institute in Education for Sustainability (ARIES).

Fien, J. (Ed).(1993) Education for the environment: Critical curriculum theorising and environmental education. Deakin University Press: Geelong.

Fien, J. (2001). Education for sustainability: Reorienting Australian schools for a sustainable future. Tela: Environment, Economy and Society, Issue 8. Brisbane: Australian Conservation Foundation, Australian Association of Environmental Education, Trust for Young Australians.

Fien, J., \& Maclean, R. (2000). In K. A. Wheeler, \& A. Perraca Bijur (Eds). Education for a sustainable future: A paradigm of hope for the $21^{\text {st }}$ century. (pp.91-111). New York: Kluwer Academic/Plenum Publishers.

Flowers, R. \& Chodkiewicz, A. (2009). Local communities and schools tackling sustainability and climate change. Australian Journal of Environmental Education, 25, 71-81.

Gallopin, G. (2003). A systems approach to sustainability and sustainable development. Santiago, Chile: United Nations. Report for the Sustainable Development and Human Settlements Division. 
Goldie, J., Douglas, B., \& Furnass, B. (2005). An urgent need to change direction. In J.Goldie, B. Douglas \& B. Furnass (Eds.), In search of sustainability). (pp. 1-15) Collingwood, Victoria: CSIRO Publishing.

Henderson, K., \& Tilbury, D. (2004). Whole-school approaches to sustainability: an international review of whole-school sustainability programs. Report by the Australian Research Institute in Education for Sustainability (ARIES) for the Australian Government Department of the Environment, Water, Heritage and the Arts.

Jickling, B., and Wals, A. (2008). Globalization and environmental education: Looking beyond sustainable development. Journal of Curriculum Studies, $40(1), 1-21$.

Lazslo, E., (2001). Macroshift: Navigating the transformation to a sustainable world. San Francisco, California:Berrett-Koehler Publishers.

Lewis, E., Baudains, C., \& Mansfield, C. (2009). The impact of AuSSI-WA at a primary school. Australian Journal of Environmental Education, 25, 45- 57.

Littledyke, M., Taylor, N., \& Eames, C. (2009). Education for sustainability in the primary curriculum: a guide for teachers. South Yarra, Australia: Palgrave, MacMillan.

Martin, K., Summers, D., \& Sjerps-Jones, H. (2007). Sustainability and teacher education. Journal of Further and Higher Education, 31(4), 351-362.

Nolet, V. (2009). Preparing sustainability-literate teachers. Teachers College Record. 111(2), 409-442.

Orr, D. (1992). Ecological literacy: Education and the transition to a postmodern world. Albany: State University of New York Press.

Orr, D. (2004). Earth in mind: On education, environment, and the human prospect. Washington, D.C: Earth Island Press.

Pepper, C., \& Wildy, H. (2008). Leading for sustainability: Is surface understanding enough? Journal of Educational Administration, 46 (5), 613-629.

Pezzoli, K.(1997). Sustainable development: A transdisciplinary overview of the literature. Journal of Environmental Planning and Management, 40 (5), 549-574.

Raudsepp, M., \& Heidmets, M. (2005). Sustainability as a regulative idea and norm of behaviour: social and psychological aspects. In W. Leal Filho(Ed), Handbook of Sustainability Research, (Vol. 20.,pp. 205-234).Frankfurt:Peter Lang.

Selby, D. (2006). The firm and shaky ground of education for sustainable development. Journal of Geography in Higher Education, 30 (2), 351-365.

Selby, D., \& Kagawa, F. (2010). Runaway climate change as challenge to the 'closing circle' of education for sustainable development. Journal of Education for Sustainable Development, 4 , 37-49.

Sterling, S. (2003). Whole systems thinking as a basis for paradigm change in education: Explorations in the contexts of sustainability. Unpublished $\mathrm{PhD}$ thesis, University of Bath, United Kingdom.

Sterling, S. (2009). Sustainable education. In D. Gray, L. Collucci-Gray and E. Camino (Eds.). Science, Society and Sustainability: Education and empowerment for an uncertain world.(pp. 105118).

Taylor,N., Nathan, S., \& Coll, R.K. (2003). Education for sustainability in regional New South Wales, Australia: An exploratory study of some teachers' perceptions. International Research in Geographical and Environmental Education, 12(4), 291-311.

Tilbury, D.C.K. (2005). A national review of environmental education and its contribution to sustainability in Australia: Frameworks for sustainability. Canberra, Australia.

Tilbury, D., \& Cooke, K. (2005). A national review of environmental education and its contribution to sustainability in A ustralia: School education. Canberra: Australian Government Department of the Environment and Heritage and Australian Research Institute in Education for Sustainability (ARIES).

Tilbury, D., \& Wortman, D. (2004). Engaging people in ststainability. IUCN: Gland. 
United Nations Education, Scientific and Cultural Organisation [UNESCO] (2002). Education for sustainability: Lessons learnt from a decade of innovation from Rio to Johannesburg. Paris: Author.

United Nations Education, Scientific and Cultural Organisation [UNESCO] (2005). Guidelines and recommendations for reorienting teacher education to address sustainability: Education for sustainable development in a ction (Technical paper No. 2). New York: Author.

United Nations Education, Scientific and Cultural Organisation [UNESCO] (2006). Framework for the UNDESD international implementation scheme. Paris: Author.

United Nations Education, Scientific and Cultural Organisation [UNESCO] (2009). Review of contexts and structures for education for sustainable development 2009. Paris: Author.

Wals, A. E. J. (2009). A mid-DESD review:Key findings and ways forward. Journal of Education for Sustainable Development, 3,195-204.

Wals, E. J., \& Jickling, B. (2002). Sustainability in higher education- from doublethink and newspeak to critical thinking and meaningful learning. International Journal of Sustainability in Higher Education, 3(3), 221 - 232.

Woolterton, S. (2003). School-as-community:Bridging the gap to sustainability. Education, Murdoch University. Doctor of Philosophy.

World Commission on Environment and Development [WCED] (1987). Our common future. Oxford, England: Oxford University Press.

\section{About the Author}

\section{Sonja Kuzich}

Sonja Kuzich is a Lecturer in Curriculum and Pedagogy at Curtin University of Technology in WA. She is currently National Secretary of the Australian Professional Teachers Association (APTA). Sonja has had a long-standing interest in pursuing wider acknowledgement (by educators themselves and within the community) of the contribution that educators make towards achievement of broader societal goals. Her research interests include social justice and equity pedagogy, teacher professionalism, revisioning educational goals, and educational policy development and implementation, particularly through a sustainability agenda (the focus of her current $\mathrm{PhD}$ ). 